\title{
Cytotoxicity of Soursop Leaves (Annona muricata) against Cervical HeLa Cancer Cells
}

\author{
Fona Qorina ${ }^{1}$, Ade Arsianti2 ${ }^{2,3}$, Qotrunnada Fithrotunnisa', NadzilaAnindya Tejaputri', Norma Nur Azizah' ${ }^{3}$, \\ Rista Putrianingsih ${ }^{2}$
}

Fona Qorina', Ade Arsianti ${ }^{2,3, *}$, Qotrunnada Fithrotunnisa', NadzilaAnindya Tejaputri', Norma Nur Azizah ${ }^{3}$, Rista Putrianingsih ${ }^{2}$

'Medical Student, Faculty of Medicine University of Indonesia, Depok, INDONESIA. ${ }^{2}$ Department of Medical Chemistry, Faculty of Medicine, University of Indonesia, Depok, INDONESIA.

${ }^{3}$ Drug Development Research Cluster, Drug Discovery Division, Indonesia Medical

Education and Research Institute (IMERI),

Faculty of Medicine, University of Indonesia, Jalan Salemba Raya 6 Jakarta 10430,

INDONESIA.

\section{Correspondence}

\section{Dr. Ade Arsiant}

Department of Medical Chemistry, Faculty of Medicine, University of Indonesia, Jalan Salemba Raya 6 Jakarta 10430 INDONESIA

Phone no. +6281312581253

Email: arsi_ade2002@yahoo.com

History

- Submission Date: 03-09-2019;

- Review completed: 10-10-2019;

- Accepted Date: 11-10-2019.

DOI : 10.5530/pj.2020.12.4

Article Available online http://www.phcogj.com/v12/i1

Copyright

(C) 2020 Phcogj.Com. This is an openaccess article distributed under the terms of the Creative Commons Attribution 4.0 International license.

\begin{abstract}
Background: Cervical cancer is the cancer with highest prevalence and the leading cause of women death in Indonesia. Current treatments available for cervical cancer are chemotherapy, radiation, surgery, and nuclear therapy. Unfortunately, these treatments still have several limitations due to serious side effects, development of resistance, and very expensive price. Therefore, it is necessary to develop effective and low-cost therapy to treat cervical cancer. One of which is by utilizing natural sources available in Indonesia such as soursop (Annona muricata) leaves which has been used in folk medicine as a treatment for various diseases, including cancer. However, studies about its cytotoxicity against cervical cancer in Indonesia are still limited. Objective: The aim of this research is to analyze the potency of A.muricataleaves extracts originated from Indonesia as a novel alternative treatment for cervical cancer. Materials and method: A.muricata leaves obtained from Serpong, West Java, Indonesia were grounded and macerated in three different solvents with various polarity, namely ethanol (polar solvent), ethyl acetate (semipolar solvent) and hexane (non-polar solvent). Subsequently, the extracts were diluted into 8 various concentrations. Cytotoxicity of A.muricataleaves extracts against HeLa cervical cancer cells were determined by MTT assay and expressed by $I C_{50}$ value. Results: The results showed that three extracts of $A$. muricata have strong cytotoxicity against cervical HeLa cells. The highest cytotoxic activity was shown by etanol extract with an $\mathrm{IC}_{50}$ of $35.51 \mu \mathrm{g} / \mathrm{mL}$, followed by ethyl acetate $\left(\mathrm{IC}_{50}: 5.91 \mu \mathrm{g} / \mathrm{mL}\right)$, and hexane $\left(I \mathrm{C}_{50}: 8.39 \mu \mathrm{g} / \mathrm{mL}\right)$. Conclusion: A.muricata leaves extracts are potential to be developed as a novel alternative therapy for cervical cancer.
\end{abstract}

Key words: Annona muricata, Soursop, Cytotoxicity, HeLa cells.

\section{INTRODUCTION}

Cancer is the leading cause of 8.8 million death globally in 2015 and ranked as the $2^{\text {nd }}$ disease with highest mortality. ${ }^{1}$ According to National Basic Health Report (Riset Kesehatan Dasar), in 2013 the prevalence of cancer in Indonesia reached 1.4 per 1,000 population. Cancer with the highest prevalance is cervical cancer with 15,000 cases annually which make it as the leading cause of women-death in Indonesia. Cervical cancer is a type of cancer that arises from the cervical surface epithelium, located on the opening of the uterus. ${ }^{2,3}$

Currently, modalities of treatment available for cervical cancer consist of chemotherapy, radiation, nuclear therapy, and surgery based on stadium of the cancer. Unfortunately, these treatments have several limitations due to serious side effects such as disrupting cell metabolism, nausea, vomitting, nephrotoxicity, anemia, ototoxicity. In addition, development of resistance to the drugs also considered as limitation of the current therapy. Another obstacle encountered is the expensive cost of treatments. ${ }^{4}$ Therefore, it is necessary to develop a novel alternative therapy which is more effective and low-cost to help the patients.

Indonesia is a tropical country with various natural resources, including herbal plants, that can be utilized as an alternative treatment. One of herbal plants that known has been widely used in Indonesian folk medicine is soursop (Annona muricata) (Figure 1). People commonly used its leaves to treat several conditions such as dermatitis, diarrhea, dysentry, fever, hypertension, diabetes, and also cancer. ${ }^{5-7}$

Based on previous research conducted by Minami et al, soursop leaves extract is reported had an anticancer activity against breast cancer cells through induction of apoptotic process. ${ }^{8}$ Another study reported that soursop leaves extracts were known to increase expression of p53 gene and lower hsp70 expression, resulted in activation of apoptosis process and stable homeostasis in Raji cells. ${ }^{9}$ However, research about cytotoxicity of Annona muricata leaves originating from Indonesia against cervical cancer are still limited. Therefore, this research aimed to analyze cytotoxicity of A.muricata leaves against cervical cancer because it is the leading cause of cancer-related death.

On the other hand, polarity of the solvents used in extraction process of herbal plant will contribute to the biological activity of the plant itself, including its cytotoxicity. Secondary metabolites contained in the plant tend to be more dissolve in the solvent with a same polarity. ${ }^{10}$ Thus, this study also explore cytotoxicity of Annona muricata extract in three different polarity solvents, which are ethanol (polar), 


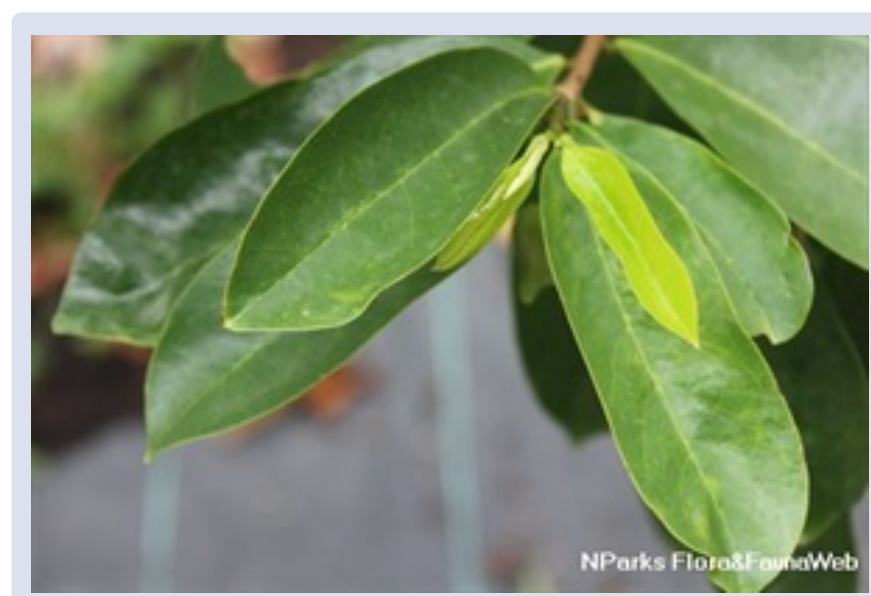

Figure 1: Morphology of Annona muricata.

Kingdom: Plantae

Divisio: Tracheophyta (Magnoliophyta)

Classes: Manoliopsida

Ordo: Magnoliales

Familia: Annonaceae

Genus: Annona L.

Species: Annonamuricata L.

ethyl acetate (semipolar), and hexane (nonpolar) to determine at which polarity A.muricata extracts show the greatest cytotoxicity against cervical cancer.

\section{METHODS}

\section{Collection and extraction of soursop leaves (Annona muricata)}

Soursop leaves originated from Serpong, Banten Province, Indonesia were washed and grinded to approximately $1000 \mathrm{~g}$ of dry powder sample. Then, the powder were macerated in $500 \mathrm{~mL}$ of three different polarity solvents which are ethanol (polar), ethyl acetate (semipolar), and hexane (nonpolar). Maceration were done three times in 24 hours. The result of maceration then filtered and concentrated with vacuum dry technique to obtain ethanol, ethyl acetate, and hexane extracts of Annona muricata leaves. Afterwards, the three extracts of A.muricatawere diluted using serial dilution method into 8 different concentrations $(1.5,3.125,6.25,12,5.25,50,100$, and $200 \mu \mathrm{g} / \mathrm{mL})$.

\section{In vitro cytotoxicity evaluation}

Cytotoxicity of Annona muricata extracts against HeLa cervical cancer cells in this research were evaluated by MTT Assay. Malignant HeLa cervical cancer cells were obtained from Department of PathologyAnatomy Faculty of Medicine University of Indonesia. Then, HeLa cervical cancer cells were cultured and diluted. Afterwards, the cells were seeded into 96-microwell with each well consist of $100 \mu \mathrm{L}$. The well was incubated for 24 hours in $\mathrm{CO}_{2}$ incubator. Complete media used in this study was mixture of DMEM, Penistrep and Fetal Bovine Serum. After 24 hours, the cells were ready to be treated with extracts of Annona muricata. Ethanol, ethyl acetate, and hexane extracts of Annona muricata were prepared by diluting them into 8 various concentration using serial dilution. Then, $100 \mu \mathrm{L}$ of each sample concentrations were added into the well with three times of duplication (triplo). Positive control used in this present study was Cisplatin and negative control was cells and culture media without addition of extract. Afterwards, the cells were incubated in $\mathrm{CO}_{2}$ incubator for another 24 hours to evaluate cytotoxicity of the sample.
On the next day, $100 \mu \mathrm{L}$ of MTT reagent with a concentration of $5 \mathrm{mg} / \mathrm{mL}$ in phosphat-buffer saline was added into the wells to determine the number of living cells. Then, the microplate was left incubated for 4 hours. After that, $100 \mu \mathrm{L}$ of DMSO was added into each well to dissolve purple formazan crystal in the medium. Furthermore, absorbance of each well was read with ELISA reader at $590 \mathrm{~nm}$. Absorbance data from the ELISA reader were transformed into inhibitory percentage using the following equation:

$\%$ Inhibiton $=1-\left(\frac{\text { absorbance of group with extract }}{\text { absorbance of control group }}\right) \times 100 \%$

$\mathrm{IC}_{50}$ value is determined by plotting of log concentration of Annona muricata extract in $\mathrm{x}$-axis versus the percentage of inhibition in $\mathrm{y}$-axis to produce linear regression equation, which is $y=(\log x) a+b$. The $\mathrm{IC}_{50}$ value $(\mathrm{x})$ were obtained by substituting $\mathrm{y}=50 \%$ to the equation.

\section{RESULTS}

Percentage of inhibition of soursop leaves (Annona muricata) against HeLa cervical cancer cells

The percentage inhibition of soursop leaves extracts against HeLa Cervical Cancer was shown in Table 1. Based on the result, percentage inhibition of extracts A.muricata ranges from $12.8 \%$ to $88.3 \%$ against cervical HeLa cells. The lowest percentage of inhibition (12.6\%) was shown by ethyl acetate extract at the concentration of $1.5 \mu \mathrm{g} / \mathrm{mL}$. Whereas, the highest percentage (88.3\%) was shown by hexane extract at the concentration of $200 \mu \mathrm{g} / \mathrm{mL}$.

Figure 2 illustrated correlation between $\%$ inhibition and concentration of each extract. As shown, it is clear that the extracts showed cytotoxicity in a dosage dependent manner. The higher concentration of the extracts resulted in higher percentage of inhibition against HeLa cervical cancer cells.

Table 1: Percentage inhibiton of $A$.muricata leaves extracts against HeLa cells.

\begin{tabular}{ccccc}
\hline \multirow{2}{*}{$\begin{array}{c}\text { Concentration } \\
(\mu \mathrm{g} / \mathrm{mL})\end{array}$} & Log & \multicolumn{3}{c}{ Average of \% Inhhibition } \\
\cline { 3 - 5 } & Concentration & Ethanol & $\begin{array}{c}\text { Ethyl } \\
\text { Acetate }\end{array}$ & Hexane \\
\hline 1.5 & 0.176091 & 28.7 & 12.6 & 22.4 \\
3.125 & 0.49485 & 40.5 & 33.5 & 40.4 \\
6.25 & 0.79588 & 43.7 & 49.3 & 43.1 \\
12.5 & 1.09691 & 64.0 & 71,3 & 63.8 \\
25 & 1.39794 & 81.7 & 79.4 & 80.8 \\
50 & 1.69897 & 83.6 & 84.6 & 85.3 \\
100 & 2.00000 & 86.2 & 86.3 & 86.5 \\
200 & 2.30103 & 88.5 & 87.5 & 88.3 \\
\hline
\end{tabular}

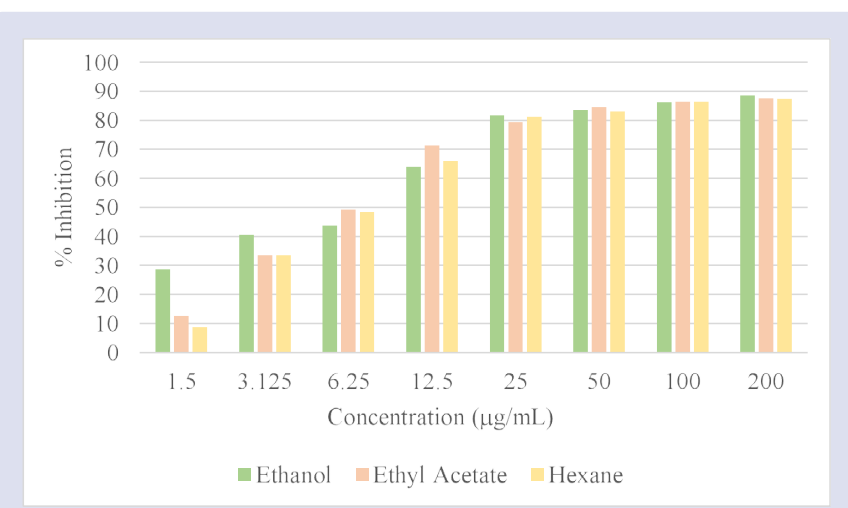

Figure 2: Correlation between concentration of extract and \% inhibition. 
Table 2: $\mathrm{IC}_{50}$ value of $A . m u r i c a t a$ extracts.

\begin{tabular}{cc}
\hline Extract of A.muricata & $\mathrm{IC}_{50}(\mu \mathrm{g} / \mathrm{mL})$ \\
\hline Ethanol & 5.91 \\
Ethyl acetate & 7.56 \\
Hexane & 8.39 \\
\hline
\end{tabular}

\section{Cytotoxic activity of soursop leaves (Annona muricata)}

Cytotoxicity of soursop leaves extracts is depicted by $\mathrm{IC}_{50}$ value. Based on the calculation using formula $10^{(50-\mathrm{b}) / \mathrm{a}}$ derived from the linear regression equation, the $\mathrm{IC}_{50}$ value of A.muricata extract were summarized in Table 2 . The $\mathrm{IC}_{50}$ value of the ethanol, ethyl acetate, and hexane extracts was found to be $5.91 ; 7.56 ; 8.39 \mu \mathrm{g} / \mathrm{mL}$, respectively. Ethanol extract of A.muricata showed the greatest cytotoxicity against HeLa cervical cancer cells compared to others, followed by ethyl acetate and hexane. The $\mathrm{IC}_{50}$ value of these three extracts were still higher when were compared to Cisplatin as a positive control $\left(\mathrm{IC}_{50}\right.$ value $=1.78 \mu \mathrm{g} /$ $\mathrm{mL})$.

\section{DISCUSSION}

This present study used MTT Assay as a method to analyze cytotoxicity of A.muricata extracts against cervical cancer HeLa cells. The basic principle of MTT assay is that it measures the reduction of yellow tetrazolium salt into purple formazan crystal. By reductase enzyme found in mitochondria of viable cells. Thus, the higher absorbance of the sample indicates the higher number of living cells. Percentage of Inhibition describes the number of cancer cells growth that can be inhibited by the extract. ${ }^{11}$ Table 1 showed the inhibitory percentage of A.muricata extracts against HeLa cervical cancer cells. The result indicates that there is a positive correlation between concentration of the extract and the inhibition percentage.

Cytotoxicity is depicted by $\mathrm{IC}_{50}$ value which means the concentration needed for the extract to inhibit $50 \%$ activity of the cancer cells. The lower $\mathrm{IC}_{50}$ value of an extract indicates the greatest cytotoxicity against cancer cells. Table 2 summarized $\mathrm{IC}_{50}$ value of three Anonna muricata leaves extract. The lowest $\mathrm{IC}_{50}$ value $(5.91 \mu \mathrm{g} / \mathrm{mL})$ was shown by ethanol extract, suggesting that ethanol extract has the greatest cytotoxicity compared to other extracts.

According to American National Cancer Institute, crude extract of a herbal plant is considered to have in vitro cytotoxicity if it shows $\mathrm{IC}_{50}$ less than $20 \mu \mathrm{g} / \mathrm{mL} .{ }^{12}$ As displayed in Table 2 , the $\mathrm{IC}_{50}$ value of all $A$. muricata extracts are less than $20 \mu \mathrm{g} / \mathrm{mL}$. Thus, it can be concluded that all extracts have active cytotoxicity against HeLa cervical cancer cells.

Previous studies have reported various mechanism of A.muricata as an anticancer agent. According to Torres $e t$ al, soursop leaves showed inhibit tumorgenicity and metastasis in pancreatic cancer by inhibiting cell metabolism. ${ }^{13}$ Another study conducted by Liu et al reported that soursop leaves could activate apoptosis process of hepatic cancer through reticulum endoplasm stress. ${ }^{14}$ In addition, Moghadamtousi also proved that soursop leaves extract could induce apoptotis process of lung cancer through mitochondria pathway. ${ }^{15}$

Anticancer activity of Annona muricata could be affected by its biological compounds. Research suggest that it comes from special compound owned by genus Annonaceae called Annonaceous acetogenin. This molecule is derivate of long chain fatty acids (C32 or C34). ${ }^{16}$ The cytotoxicity mechanism of this molecule is by inhibiting complex I in mitochondria and reduce the ATP production in cytoplasm, resulting in disruption of oxidative phosphorylation and leads to activation of apoptosis process. Cancer cells require more ATP than normal cells because they are constantly growing. Thus, it makes cancer cells more susceptible to Annonaceous acetogenin rather than normal cells. ${ }^{17} \mathrm{On}$ the other hand, Annonaceous acetogenin is a polar compound which is more easier to dissolve in polar solvent. This could explain the result from this study which showed that ethanol extract with the highest polarity has the greatest cytotoxicity compared to other extracts.

Another biological compound contributes to anticancer effect of Annona muricata is flavonoid, as reported by Yang et al. The administration of soursop leaves extract has been shown to inhibit the growth of prostatic cancer. Flavonoid is also a polar compound and it is more likely to dissolve in polar solvents. Mechanism of flavonoid as an anticancer including induction of apoptosis, inhibition of cells proliferation, and inhibition of lipid peroxidation. ${ }^{18}$

\section{CONCLUSION}

This research clearly demonstrate that three extracts of A.muricata have a strong cytotoxicity against HeLa cervical cancer cells with the greatest cytotoxicity was shown by ethanol extract $\left(\mathrm{IC}_{50}=5.91 \mu \mathrm{g} / \mathrm{mL}\right.$ ). Thus, extracts of A.muricata are potential to be developed as a novel alternative therapy for cervical cancer.

\section{ACKNOWLEDGEMENT}

We wish to express our gratitude to Directorate of Research and Public Service University of Indonesia for PITTA B (Publikasi International Terindeks Scopus untuk Tugas Akhir Mahasiswa B) research grant fiscal year 2019 .

\section{CONFLICTS OF INTEREST}

The authors declare no conflicts of interest.

\section{ABBREVIATIONS}

MTT: (3-(4,5-Dimethylthiazol-2-yl)-2,5-Diphenyltetrazolium Bromide); $\mathrm{IC}_{50}$ : Inhibition Concentration 50\%; \%: Percentage; $\mu \mathrm{g}$ : Microgram; nm: Nanometer; g: Gram; mL: Millimeter; nm: Nanometer; PBS: Phosphate- Buffered Saline; HeLa: Henrietta $\mu \mathrm{l}$ : Microliter; $\mathrm{CO}_{2}$ : Carbon dioxide; $\mu \mathrm{g} / \mathrm{mL}$ : Microgram/milliliter.

\section{REFERENCES}

1. WHO. Cancer[Internet]. Geneva: WHO. 2017.[cited at 2018 Jan 26]. Available from: http://www.who.int/mediacentre/factsheets/fs297/en/.

2. Badan Penelitian dan Pengembangan Kesehatan. Riset kesehatan dasar Jakarta: Kementerian Kesehatan Republik Indonesia. 2013.

3. Komite Penanggulangan Kanker Nasional. Panduan penatalaksanaan kanker serviks. Jakarta: Kementrian Kesehatan Rl; date unknown.

4. Hoffman B, Schorge J, Bradshaw K, Halvorson L, Schaffer J, Corton M. Williams gynecology. 3rd ed. New York: Mc Graw Hill. 2016. Pp: 654-68.

5. Gavamukulya Y, Wamunyokoli F, El-Shemy HA. Annona muricata: Is the natura therapy to most disease conditions including cancer growing in our backyard? A systematic review of its research history and future prospect. Asian Pac J Trop Med. 2017;10(9):835-48.

6. Coria-Téllez AV, Montalvo-Gónzalez E, Yahia EM, Obledo-Vázquez EN Annona muricata: A comprehensive review on its traditional medicinal uses, phytochemicals, pharmacological activities, mechanisms of action and toxicity. Arab J Chem. 2015.

7. National Parks Board. Annona muricata [Internet]. Singapore: NParks Flora \& Fauna; 2013 [cited at 2018 Jun 28]. Available from: https://florafaunaweb. nparks.gov.sg/Special-Pages/plant-detail.aspx?id=3258.

8. Minami E. Anticancer activity test of ethyl acetate extract of endophytic fungi isolated from soursop leaf. Asian Pacific Journal of Tropical Medicine. 2017; 10(6):566-71.

9. Astirin OP, Prayitno A, Artanti AN, Fitria MS. The expression of p53 and hsp70 proteins after treatment with Annona muricata Linn leaf for activating apoptotic and lead to homeostasis program of Raji cells Technical Report Abstract. Int $J$ Cancer Oncol. 2014;2(2):1-6.

10. Thouri A, Chahdoura H, El Arem A, Omri Hichri A, Ben Hassin R, Achour L. Effect of solvents extraction on phytochemical components and biological activities of Tunisian date seeds (var. Korkobbi and Arechti). BMC Complement Altern Med. 2017;17(1):248

11. American Type Culture Collection. MTT Cell Proliferation Assay Instruction Guide. Components. 2011;6597:1-6. 
12. Sriwiriyajan S, Ninpesh T, Sukpondma Y, Nasomyon T, Graidist P. Cytotoxicity screening of plants of genus Piper in breast cancer cell lines. Trop J Pharm Res. 2014;13(1):921-8

13. Torres MP, Rachagani S, Purohit V, Pandey P, Joshi S, Moore ED, et al. Graviola: A novel promising natural-derived drug that inhibits tumorigenicity and metastasis of pancreatic cancer cells in vitro and in vivo through altering cell metabolism. Cancer Lett. 2012;323(1):29-40.

14. Liu N, Yang HL, Wang P, Lu YC, Yang YJ, Wang L, et al. Functional proteomic analysis revels that the ethanol extract of Annona muricata $L$. induces liver cancer cell apoptosis through endoplasmic reticulum stress pathway. J Ethnopharmacol. 2016;189:210-7.

15. Moghadamtousi SZ, Kadir HA, Paydar M, Rouhollahi E, Karimian H. Annona muricata leaves induced apoptosis in A549 cells through mitochondrial- mediated pathway and involvement of NF- $\kappa$ B. BMC Complement Altern Med 2014; 14:299.

16. Gupta A, Pandey S, Shah D, Yadav J, Seth N. Annonaceous acetogenins: the unrevealed area for cytotoxic and pesticidal activities. Sys Rev Pharm. $2011 ;(2): 104-9$.

17. $\mathrm{NCl}$ Dictionary. Definition of Annonaceous acetogenins - NCl Drug Dictionary - National Cancer Institute [Internet]. National Cancer Institute. [cited 2019 Jun 17]. Available from: https://www.cancer.gov/publications/dictionaries/cancerdrug/def/annonaceous-acetogenins.

18. Yang C, Gundala SR, Mukkavilli R, Vangala S, Reid MD, Aneja R. Synergistic interactions among flavonoids and acetogenins in Graviola (Annona muricata) leaves confer protection against prostate cancer. Carcinogenesis. 2015;36(6):656-65

\section{GRAPHICAL ABSTRACT}

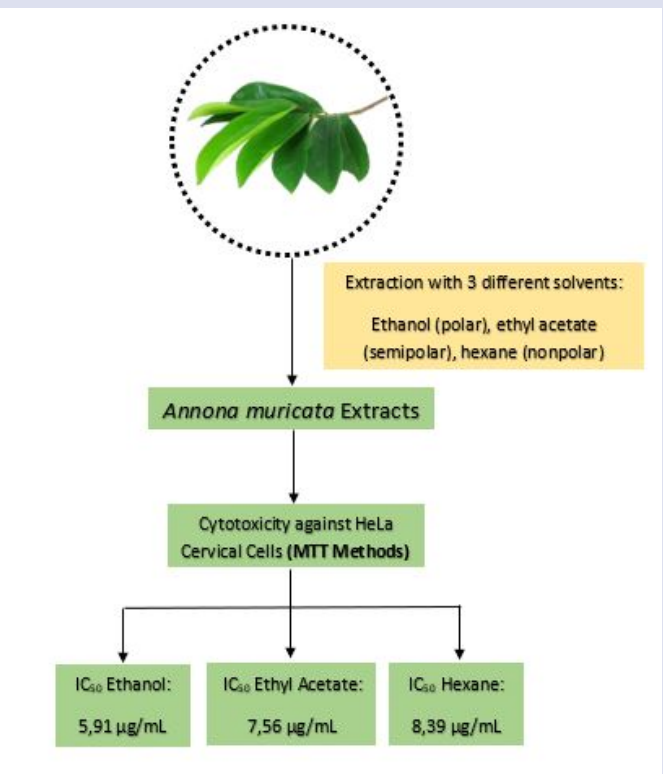

\section{ABOUT AUTHORS}

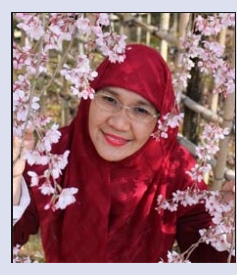

Dr. Ade Arsianti : Lecture and Researcher at Medical Chemistry and Drug Development Research Center, Indonesian Medical Education and Research Institute, Faculty of Medicine, Universitas Indonesia. Research interest medicinal chemistry, Synthetic Organic Chemistry and natural product chemistry.

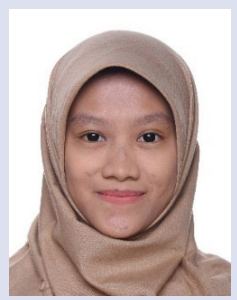

Fona Qorina: Medical Student, Faculty of Medicine, Universitas Indonesia. Research interest in herbal medicine, cancer biology, cardiovascular and metabolic disease.

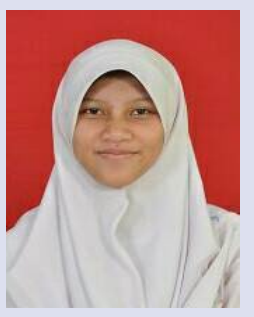

Nadzila Anindya Tejaputri: Medical Student, Faculty of Medicine, Universitas Indonesia. Research interest in herbal medicine, cancer biology, pediatric disease, and mental health science. 


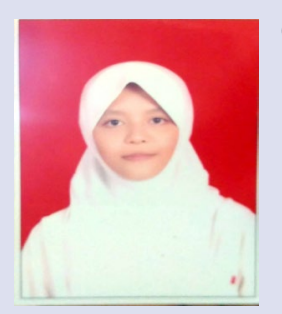

Qotrunnada Fithrotunnisa: Medical Student, Faculty of Medicine, Universitas Indonesia. Research interest in herbal medicine and cancer biology.

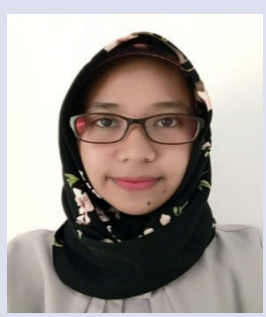

Norma Nur Azizah: Researcher at Drug Development Research Center, Indonesian Medical Education and Research Institute, Faculty of Medicine, Universitas Indonesia. Research interest tissue culture, analytical chemistry, and natural product chemistry in drug development.

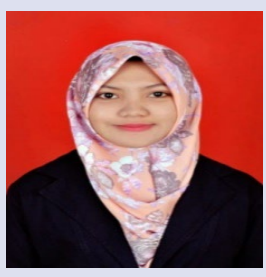

Rista Putrianingsih: Researcher at Medical Chemistry, Faculty of Medicine, Universitas Indonesia. Research interest tissue culture and natural product chemistry.

Cite this article: Qorina F, Arsianti A, Fithrotunnisa A, Tejaputri N, Azizah NN, Putrianingsih R. Cytotoxicity of Soursop Leaves (Annona muricata) against Cervical HeLa Cancer Cells. Pharmacog J. 2020;12(1):20-4. 